\title{
Biodiesel Production from Waste Cooking Oil Using Sulfuric Acid and Microwave Irradiation Processes
}

\author{
Prafulla D. Patil, Veera Gnaneswar Gude, Harvind K. Reddy, Tapaswy Muppaneni, Shuguang Deng*
}

Chemical Engineering Department, New Mexico State University, Las Cruces, USA.

Email: ${ }^{*}$ sdeng@nmsu.edu

Received July $30^{\text {th }}, 2011$; revised October $1^{\text {st }}, 2011$; accepted November $15^{\text {th }}, 2011$

\begin{abstract}
A comparative study of biodiesel production from waste cooking oil using sulfuric acid (Two-step) and microwaveassisted transesterification (One-step) was carried out. A two-step transesterification process was used to produce biodiesel (alkyl ester) from high free fatty acid (FFA) waste cooking oil. Microwave-assisted catalytic transesterification using $\mathrm{BaO}$ and $\mathrm{KOH}$ was evaluated for the efficacy of microwave irradiation in biodiesel production from waste cooking oil. On the basis of energy consumptions for waste cooking oil (WCO) transesterification by both conventional heating and microwave-heating methods evaluated in this study, it was estimated that the microwave-heating method consumes less than $10 \%$ of the energy to achieve the same yield as the conventional heating method for given experimental conditions. The thermal stability of waste cooking oil and biodiesel was assessed by thermogravimetric analysis (TGA). The analysis of different oil properties, fuel properties and process parametric evaluative studies of waste cooking oil are presented in detail. The fuel properties of biodiesel produced were compared with American Society for Testing and Materials (ASTM) standards for biodiesel and regular diesel.
\end{abstract}

Keywords: Biodiesel; Waste Cooking Oil; Free Fatty Acid; Sulfuric Acid; Microwave-Assisted Transesterification

\section{Introduction}

The current methods to produce, convert and consume energy derived from fossil fuels throughout the world are not sustainable. Due to limited amounts of fossil fuels and increasing concerns of global warming, there is evergrowing urge to develop fuel substitutes that are renewable and sustainable. Biomass derived fuels such as methane, ethanol, and biodiesel are well-accepted alternatives to diesel fuels as they are economically feasible, renewable, environmental-friendly and can be produced easily in rural areas where there is an acute need for modern forms of energy.

Edible vegetable oils such as canola, soybean, and corn have been used for biodiesel production and are proven diesel substitutes [1,2]. However, a major obstacle in the commercialization of biodiesel production from edible vegetable oils is their high production cost, which is due to the demand for human consumption. Reducing the cost of the feedstock is necessary for biodiesel's longterm commercial viability. One way to reduce the cost of this fuel is to use less expensive feedstocks including waste cooking oils and vegetable oils that are non-edible and/or require low harvesting costs. Waste cooking oil

"Corresponding author.
(WCO), which is much less expensive than edible vegetable oil, is a promising alternative to edible vegetable oil [3]. Waste cooking oil and fats set forth significant disposal problems in many parts of the world. This environmentally-threatening problem could be turned into both economical and environmental benefit by proper utilization and management of waste cooking oil as a fuel substitute. Many developed countries have set policies that penalize the disposal of waste cooking oil into waste drainage [4]. The Energy Information Administration (EIA) in the United States (USA) estimated that around 100 million gallons of waste cooking oil is produced per day in USA, where about 9 pounds of waste cooking oil are generated per person per year [5]. The estimated amount of waste cooking oil collected in Europe is about $0.49-0.7$ million gallons/day [6]. Waste cooking oil, as an alternative feedstock for biodiesel, was studied with different aspects such as optimization using supercritical methanol (SCM) transesterification, process design and technological assessment, fuel property analysis and cost estimation approaches [7-9].

Biodiesel is derived from fats and oils either by chemical or bio-chemical means [10]. There are at least four ways in which oils and fats can be converted into biodiesel, namely, transesterification, blending, micro- 
emulsions and pyrolysis. Among these, transesterification is the most commonly used method as it reduces the viscosity of oil [11]. Biodiesel production by transesterification reaction can be catalyzed with alkali, acidic or enzymatic catalysts. Alkali and acid transesterification processes require less reaction time with reduced processing costs as compared to the enzyme catalyst process $[12,13]$. Alkali process yields high quantity and high purity biodiesel in shorter reaction time [14]; however, this process is not suitable for feedstock with high free fatty acid (FFA) content. Therefore, a two-step transesterification process (acid esterification followed by alkali transesterification) was developed to remove high free fatty acid (FFA) content and to improve the biodiesel yield. The long reaction time and low recovery of catalyst were disadvantages of the two-step process. An alternative method, namely the microwave-assisted catalytic transesterification, has been developed that gives high biodiesel yield and purity. Microwave-assisted transesterification is an energy-efficient and a quick process to produce biodiesel from different feedstocks $[15,16]$. Microwave-heating has been successfully applied to synthesize porous materials and supported catalyst in our previous research [17,18]. Microwave-assisted transesterification of different feedstocks such as rapeseed oil, cotton seed oil and waste cooking oils has been reported by several researchers $[15,19,20]$.

In this research, we have conducted several experiments to compare the biodiesel production from waste cooking oil using sulfuric acid (Two-step) and microwave-assisted transesterification (One-step) processes. Since waste cooking oil contains high FFA content, a two-step process, acid esterification followed by alkali transesterification was employed using methanol, sulfuric acid and $\mathrm{KOH}$ catalyst. Microwave-assisted catalytic transesterification using $\mathrm{BaO}$ and $\mathrm{KOH}$ was studied for waste cooking oil to compare with the conventional heating method. Energy requirements for both conventional and microwave heating methods and product separation times were compared.

\section{Methodology}

Waste cooking oil (WCO) was collected from a local restaurant in Las Cruces, NM. Potassium hydroxide flakes, methanol (AR Grade), and diethyl ether were procured from Fisher Scientific, New Jersey. Sulfuric acid (98\% pure) was procured from Acros Organics, New Jersey. The mixture was stirred at the same speed for all test runs. All experiments of transesterification reaction were performed in a $250 \mathrm{~mL}$ round-bottom flask equipped with a water-cooled reflux condenser. A hot plate with magnetic stirrer arrangement was used for heating the mixture in the flask. The microwave-assisted transesterification was performed using a modified do- mestic microwave oven (with an output power of $800 \mathrm{~W}$ ). The microwave oven was modified and fitted with a temperature reader, an external agitator and a watercooled reflux condenser.

\subsection{Characteristics of Waste Cooking Oil}

The quality of oil is expressed in terms of the physicochemical properties such as acid value, saponification value, and iodine value. The saponification value of waste cooking oil (WCO) was reported as 186.3 (mg $\mathrm{KOH} / \mathrm{g}$ ). The acid value of waste cooking oil was found to be $17.41 \mathrm{mg} \mathrm{KOH} / \mathrm{gm}$. It has been reported that transesterification would not occur if FFA content in the oil were above $3 \mathrm{wt} \%$ [21].

\subsection{Transesterification Reaction}

The transesterification process was widely used in biodiesel production from different biomass materials. The process consists of two steps namely, acid esterification and alkali transesterification [22]: Step 1: Acid esterification: Acid esterification reduces the FFA value of unrefined oil using an acid catalyst. Step 2: Alkali transesterification: After removing the impurities of the product from the Step 1, it is transesterified to monoesters of fatty acids using an alkali catalyst.

The mechanism of synthesis of biodiesel via two-step transesterification process is represented as

Acid Esterification (Step 1)

$$
\mathrm{RCOOH}+\mathrm{CH}_{3} \mathrm{OH} \stackrel{\mathrm{H}_{2} \mathrm{SO}_{4}}{\longrightarrow} \mathrm{RCOOH}_{3}+\mathrm{H}_{2} \mathrm{O}
$$

Acid Transesterification (Step 2)

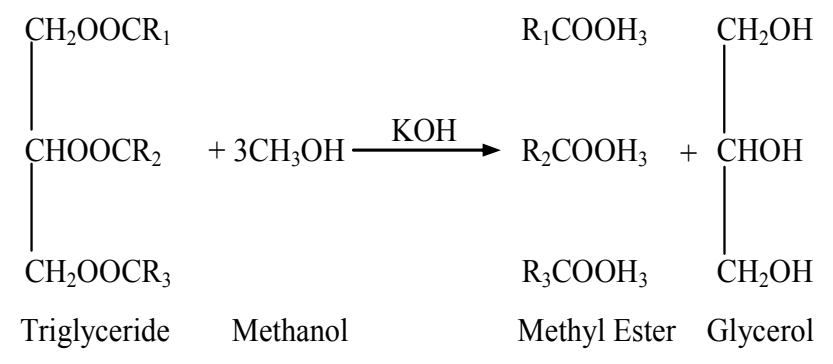

For microwave transesterification procedure, the calculated amount of waste cooking oil was added to the premixed solution of methanol and catalysts $(\mathrm{KOH}$ and $\mathrm{BaO}$ ). The mixture was then subjected to the microwave irradiation with exiting power of $800 \mathrm{~W}$, under a matrix of conditions: methanol to oil molar ratio of $6: 1$ to $15: 1$; catalyst concentrations in the range $1-2 \mathrm{wt} \%$ of oil with constant reaction time of 6 min. The purification and separation steps (downstream procedure) are described elsewhere [23].

\subsection{Analysis of Biodiesel}

For the quantification of reaction products, the samples 
were analyzed by a gas chromatography-mass spectrometry (GC-MS) system incorporated with an Agilent 5975 C mass-selective detector (MSD) and an Agilent 7890 A gas chromatograph equipped with a capillary column (HP-5 MS, 5\% phenyl methyl silox $30 \mathrm{~m} \times 250 \times$ $\mu \mathrm{m} \times 0.25 \mu \mathrm{m}$ nominal $)$. Methyl heptadecanoate $(10.00$ $\mathrm{mg}$; internal standard) was dissolved in $1 \mathrm{~mL}$ heptane to prepare the standard solution. Approximately $55 \mathrm{mg}$ methyl ester was dissolved in $1 \mathrm{~mL}$ standard solution for GC analysis. Approximately $1 \mu \mathrm{L}$ sample was injected into the GC. Helium was used as the carrier gas. The injection was performed in splitless mode. The parameters of the oven temperature program consist of: start at $80^{\circ} \mathrm{C}$ with $10^{\circ} \mathrm{C} / \mathrm{min}$ intervals up to $180^{\circ} \mathrm{C}(1 \mathrm{~min})$ and up to $255^{\circ} \mathrm{C}$ with $15^{\circ} \mathrm{C} / \mathrm{min}$ intervals $(2 \mathrm{~min})$. The Fatty acid methyl ester (FAME) content was calculated by use of the equation:

$$
C=\frac{\left(\sum A\right)-A_{E I}}{A_{E I}} \times \frac{C_{E I} \times V_{E I}}{W} \times 100 \%
$$

The biodiesel yield is apparently same to that of the FAME Content $(\%)$ calculated quantitatively by GC-MS [24]. Where $\sum A$-total peak area of methyl ester, $A_{E I}$ peak area of methyl heptadeconoate, $C_{E I}$ concentration ( $\mathrm{mg} / \mathrm{mL})$ of standard solution (methyl heptadecanoate), $V_{E I}$-volume $(\mathrm{mL})$ of standard solution (methyl heptadecanoate) and $W$-weight (mg) of sample. From GCMS and TIC analysis, it can be noted that waste cooking biodiesel contains major proportion of unsaturated fatty acids.

\section{Results and Discussion}

\subsection{Sulfuric Acid Process (Two-Step Transesterification)}

Acid esterification reaction was studied for four different molar ratios. The sulfuric acid catalyst amount was varied in the range of $0.3 \%$ to $2 \%$. These percentages are based on volume of the oil used for the acid esterification reaction. The catalyst amount also affects the yield of process is shown in Figure 1. The acid-catalyst process attained maximum yield for waste cooking oil at $0.5 \%$ catalyst concentration. It was observed that the yield started to decline when the catalyst concentration was increased to above $0.5 \%$.

Methanol to oil molar ratio was varied for waste cooking oil within the range of $3: 1$ to $9: 1$. The maximum biodiesel yield for waste cooking oil was found at the methanol to oil molar ratio of 6:1 in acid esterification. In alkali transesterification, the maximum yield for waste cooking oil was obtained at the methanol to oil molar ratio of $9: 1$. The yield remains the moreover same with further increase in the methanol to oil molar ratio. The excess methanol in the ester layer can be removed by distillation. Canakci and Van Gerpan [25] advocate the use of large excess quantities of methanol (15:1-35:1) while using the sulphuric acid as catalyst. Figure 2 shows the methanol to oil molar ratio effect in alkali transesterification (Step 2). At higher levels, an excess methanol amount may reduce the concentration of the catalyst in the reactant mixture and retard the transesterification reaction [26].

An alkali catalyst was studied in the range of $0.3 \%$ to $2.5 \%$ using $\mathrm{KOH}$ as an alkali catalyst. The influence of the alkali catalyst amount on the yield is shown in Figure 3. The maximum yield was achieved for waste cooking oil at $2 \%$ of catalyst loading. During the experiments, it was also observed that transesterification could not take place properly with an insufficient amount of an alkali catalyst loading. The production yield slightly decreased above $2 \%$ of catalyst loading. At higher concentrations, the intensification of mass transfer became more important than increasing the amount of catalyst. The reaction temperature effect on the yield was studied in the temperature range of $40^{\circ} \mathrm{C}$ to $100^{\circ} \mathrm{C}$ at atmospheric

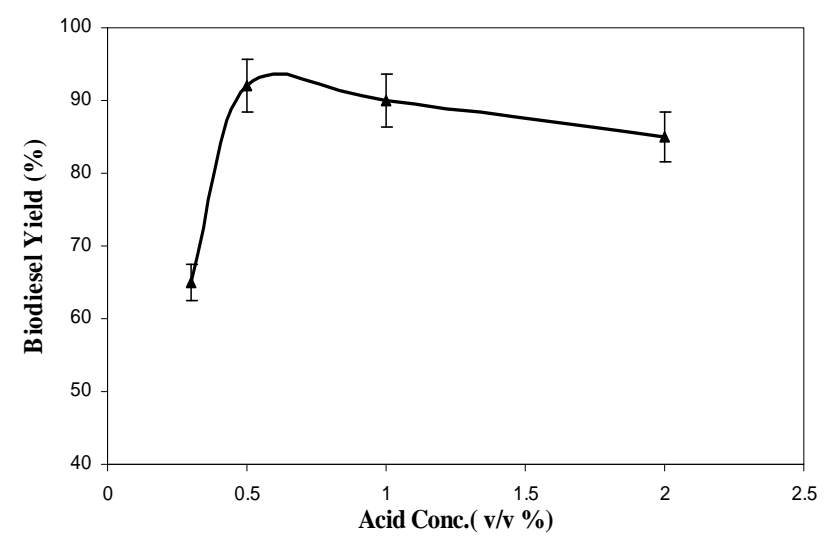

Figure 1. Effect of acid concentration on biodiesel yield (Step 1) in sulfuric acid process.

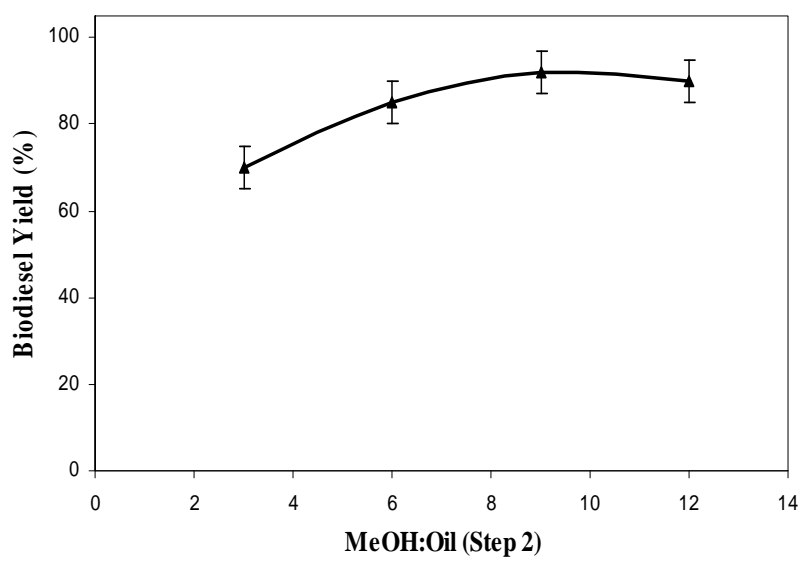

Figure 2. Effect of molar ratio on biodiesel yield (Step 2) in sulfuric acid process. 


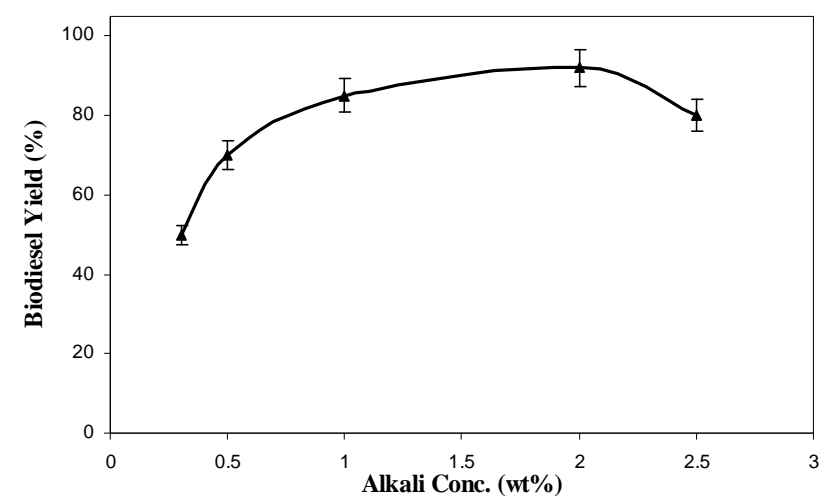

Figure 3. Effect of alkali catalyst amount on biodiesel yield (Step 2) in sulfuric acid process.

pressure. The maximum yield was obtained at a temperature of $80^{\circ} \mathrm{C}$ for waste cooking oil.

\subsection{Microwave Catalytic Transesterification}

The effect of methanol to oil molar ratio and catalyst concentration $(\mathrm{BaO}$ and $\mathrm{KOH})$ on waste biodiesel yield using microwave method. Methanol-to-oil ratios of $6: 1$, 9:1, 12:1, and 15:1 were tested for both catalysts. In this study, for homogeneous catalysts $(\mathrm{KOH})$, a molar ratio of $9: 1$ and $2 \%$ catalyst were found to be effective with maximum biodiesel yield of $92 \%$ (Figure 4). For $\mathrm{BaO}$, a maximum biodiesel yield of $96 \%$ was obtained for $12: 1$ methanol to oil molar ratio and $2 \%$ catalyst concentration (Figure 5). It was observed for homogeneous catalyst that when the amount of methanol-to-oil molar ratio was increased over 9:1, excess methanol started to interfere in the separation of glycerin due to an increase in the solubility and resulted in lower biodiesel yield [27].

In combine effect of excess alcohol and $\mathrm{KOH}$ catalyst leads to saponification resulting in lower biodiesel yield and lower biodiesel quality. An advantage associated with heterogeneous catalysts is that they can be recovered and reused several times. For homogeneous catalysts, the biodiesel separation and catalyst recovery from reaction mixture can be laborious. The reactivity of $\mathrm{BaO}$ catalyst was found to be quite different than $\mathrm{KOH}$ catalyst as it posses different catalytic activity, basicity, leaching tendency, and specific surface area, which influence the transesterification of oil [28].

Energy requirements for the two heating methods (microwave and conventional) for waste cooking oil transesterification are presented in Table 1. It can be noted that that $6 \mathrm{~min}$ were sufficient for microwave heating while $105 \mathrm{~min}$ were required for conventional heating to achieve comparable biodiesel yields. This large difference in reaction time can be attributed to the limitations of conventional heating in which the energy is first utilized to increase the temperature of the reaction vessel and the higher temperature of the reaction vessel results in higher heat losses to the ambient. The energy required by the conventional method is found to be around 11 times greater than that by the microwave method to achieve same biodiesel yield for waste cooking oil. From our previous study for camelina oil transesterification, it was concluded that proper power dissipation control resulted in effective use of the microwave energy and further reduction in energy requirements [23].

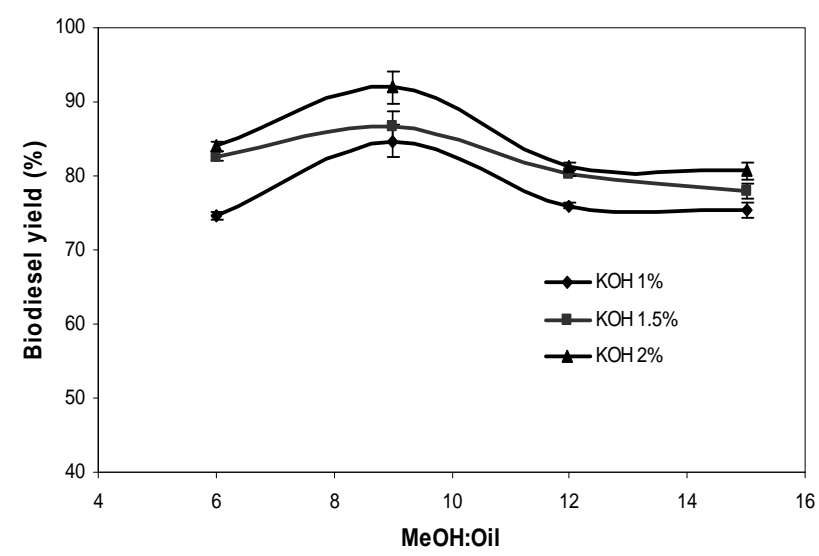

Figure 4. Effect of methanol to oil molar ratio and catalyst concentration $(\mathrm{KOH})$ on biodiesel yield using microwave method.

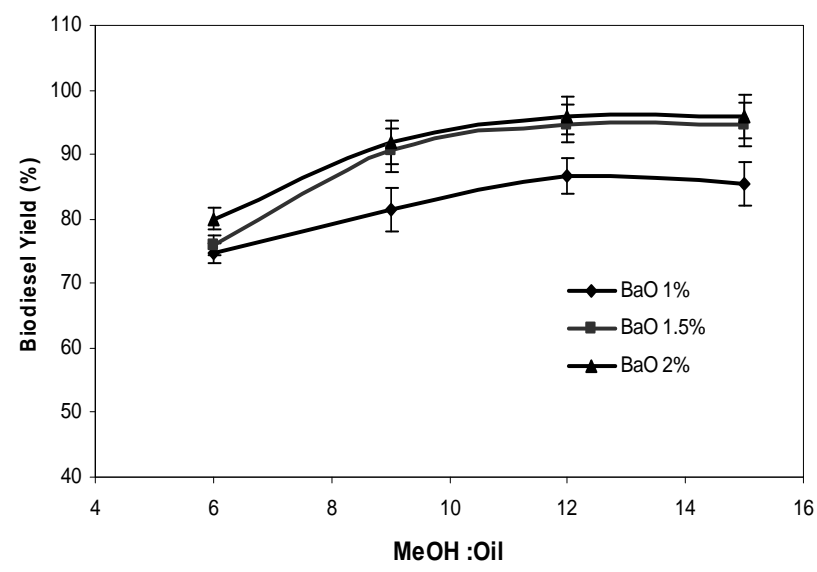

Figure 5. Effect of methanol to oil molar ratio and catalyst concentration $(\mathrm{BaO})$ on biodiesel yield using microwave method.

Table 1. Comparison of energy consumptions for biodiesel production from waste cooking oil by two methods.

\begin{tabular}{llll}
\hline & $\begin{array}{l}\text { Microwave } \\
\text { heating }\end{array}$ & $\begin{array}{l}\text { Conventional } \\
\text { heating }\end{array}$ & Catalyst \\
\hline Energy dissipated (J/s) & 800 & 500 & \\
Time of reaction $(\mathrm{s})$ & 360 & 6300 & $\mathrm{KOH}$ \\
\% Power emitted & 100 & 100 & \\
Total energy required (kJ) & 288 & 3150 & \\
Ratio & 1 & 10.93 & \\
Biodiesel yield $(\%)$ & 92 & 92 & \\
\hline
\end{tabular}


The major benefits of microwave-assisted transesterification over conventional heating are: 1) Rate Enhancement: reaction times can be drastically reduced from hours to minutes; 2) Increased yield: shorter reaction time minimizes unwanted side reactions; 3) Improved purity: less by-products result in simplified purification.

\subsection{Thermogravimetric Analysis of Waste Cooking Oil and Biodiesel}

Thermogravimetric analysis (TGA) is a technique for characterizing thermal stability of a material (compound or mixture) by measuring changes in its physicochemical properties expressed as weight change as a function of increasing temperature [29]. TGA is a simple, convenient, and economical method for monitoring biodiesel production.

Figure 6 shows the TGA plot for waste cooking oil, biodiesel and mixture of oil and biodiesel (50\% - 50\%). TGA was performed on PerkinElmer Pyris 1 TGA instrument. The temperature range employed was $25^{\circ} \mathrm{C}$ $600^{\circ} \mathrm{C}$. The mass of the waste cooking biodiesel starts to decrease at approximately after $125^{\circ} \mathrm{C}-130^{\circ} \mathrm{C}$, and this step was attributed to vaporization of biodiesel, and the second step started to decrease at $232^{\circ} \mathrm{C}$, and it may be due to some waste cooking oil that was not transesterified. TGA curve of waste cooking biodiesel did not show any step afterwards, confirmed that the transesterification reaction was complete. Similarly, evaporation of waste cooking oil starts at approximately $325^{\circ} \mathrm{C}$. TGA curve for waste cooking oil and biodiesel $(50 \%-50 \%)$ mixture confirmed the combine effect of both samples at respective temperatures as discussed above. For mixture, it was recorded that $0.9 \%$ loss of sample at $125^{\circ} \mathrm{C}, 41.54 \%$ loss at $232^{\circ} \mathrm{C}$ and $98 \%$ loss at $460^{\circ} \mathrm{C}$. The percentage of biodiesel and waste cooking oil in a sample could be calculated from the TGA plot of the sample taking into account the first derivative of the weight change of the sample mixture.

In addition, the mass loss recorded for biodiesel at $125^{\circ} \mathrm{C}$ correlates the mass percentage of biodiesel present in the sample. Likewise, the mass loss associated with waste cooking oil (ca. $325^{\circ} \mathrm{C}$ ) correlates to the mass percentage of waste cooking oil in the sample. Because of these temperatures vary by a relatively large value (approx $200^{\circ} \mathrm{C}$ ), this method should be quite effective in distinguishing biodiesel from waste cooking oil.

\subsection{Fuel Properties of Methyl Esters}

The fuel properties of biodiesel from waste cooking oil (WCO) obtained from microwave process with testing methods are given in Table 2. The viscosities of biodiesel from waste cooking oil was closer to that of viscosity of regular diesel i.e. $2.6 \mathrm{~mm}^{2} / \mathrm{s}$. Hence, no hardware modifications are required for handling this fuel (biodiesel) in the existing engine. The calorific value of waste cooking oil ester was reported in the range of $45.08-45.24 \mathrm{MJ} / \mathrm{kg}$. The cetane number was found to be higher than ASTM standards for biodiesel. Higher cetane number indicates good ignition quality of fuel. The pour point of waste cooking biodiesel was found to be in between $-4^{\circ} \mathrm{C}-1^{\circ} \mathrm{C}$. This pour point might give rise to low running problems in cold season. This problem could be overcome by the addition of suitable pour point depressants or by blending with diesel oil.

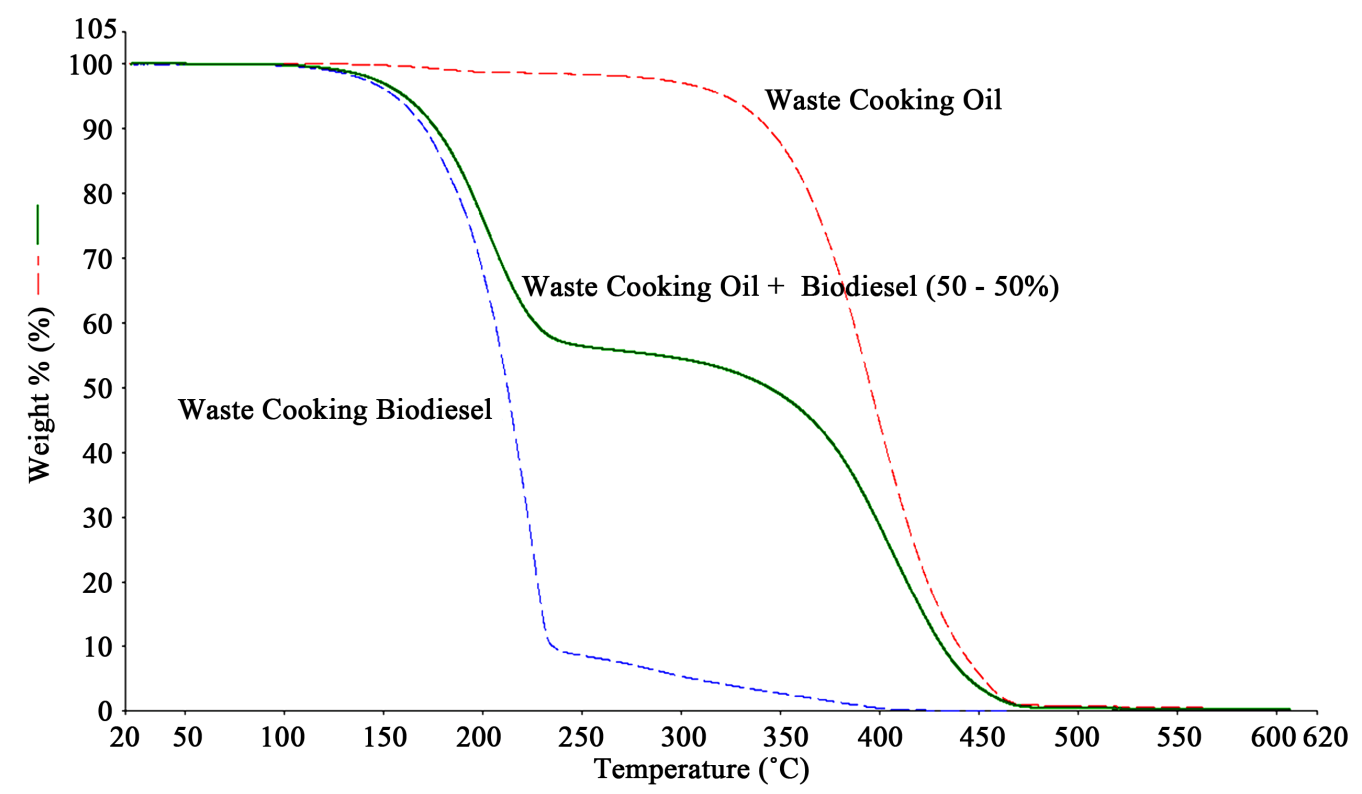

Figure 6. Overlay of thermogravimetric curves for waste cooking oil, biodiesel and mixture (50\% - $50 \%)$ of waste cooking oil and biodiesel. 
Table 2. Properties of methyl ester from waste cooking oil.

\begin{tabular}{|c|c|c|c|c|c|}
\hline Properties & $\begin{array}{c}\text { Waste } \\
\text { Cooking Oil }\end{array}$ & $\begin{array}{l}\text { Waste cooking } \\
\text { methyl ester }\end{array}$ & $\begin{array}{l}\text { Biodiesel standard } \\
\text { ASTM D 6751-09 }\end{array}$ & Regular diesel & Testing method \\
\hline Specific Gravity & 0.92 & $0.87-0.88$ & $0.86-0.90$ & 0.85 & ASTM D4052 \\
\hline Viscosity $\left(\mathrm{mm}^{2} / \mathrm{s}\right)$ at $40^{\circ} \mathrm{C}$ & 28.8 & $2.25-3.10$ & $1.9-6.0$ & 2.6 & ASTM D445 \\
\hline Calorific Value (MJ/kg) & 44.44 & $45.08-45.24$ & Report & 42 & ASTM D240 \\
\hline Cetane Number & 32.48 & $55.45-56.10$ & $47 \mathrm{~min}$. & 46 & ASTM D613 \\
\hline Pour Point $\left({ }^{\circ} \mathrm{C}\right)$ & -12 & -4 to -1 & Report & -20 & ASTM D97 \\
\hline
\end{tabular}

\section{Conclusion}

The production of fuel quality biodiesel from low-cost high FFA waste cooking oil was investigated. A two-step transesterification process was used to convert the high free fatty acid oil to its ester. Microwave-assisted transesterification of waste cooking oil using heterogeneous and homogeneous was investigated for optimum reaction conditions. The preliminary experimental study performed in this work has demonstrated that the microwave-heating method is energy-efficient and better than the conventional heating method.

\section{Acknowledgements}

This project was partially supported by US Department of Energy (DE-EE0003046) and US Air Force Research Laboratory (FA8650-11-C-2127).

\section{REFERENCES}

[1] B. Freedman, R. O. Butterfield and E. H. Pryde, "Transesterification Kinetics of Soybean Oil," Journal of the American Oil Chemists' Society, Vol. 63, No. 10, 1986, pp. $1375-1380$.

[2] X. Lang, A. K. Dalai, N. N. Bakhashi and M. J. Reaney, "Preparation and Characterization of Biodiesels from Various Bio-Oils," Bioresource Technology, Vol. 80, No. 1, 2002, pp. 53-62. doi:10.1016/S0960-8524(01)00051-7

[3] M. Canakci and J. Van Gerpen, "A Pilot Plant to Produce Biodiesel from High Free Fatty Acid Feedstocks," Journal of the American Society of Agricultural and Biological Engineers, Vol. 46, No. 4, 2003, pp. 945-954.

[4] M. G. Kulkarni and A. K. Dalai, "Waste Cooking OilAn Economical Source for Biodiesel: A Review," Industrial \& Engineering Chemistry Research, Vol. 45, No. 9, 2006, pp. 2901-2913. doi:10.1021/ie0510526

[5] A. Radich, "Biodiesel Performance, Costs, and Use," US Energy Information Administration, 2006. http://www.eia.doe.gov/oiaf/analysispaper/biodiesel/idex html

[6] B. Supple, R. Holward-Hildige, E. Gonzalez-Gomez and J. J. Leashy, "The Effect of Stream Treating Waste Cooking Oil on the Yield of Methyl Ester," Journal of the American Oil Chemists' Society, Vol. 79, No. 2, 2002, pp. 175-178.
[7] A. Chhetri, K. Watts and M. Islam, "Waste Cooking Oil as an Alternative Feedstock for Biodiesel Production," Energies, Vol. 1, No. 1, 2008, pp. 3-18. doi:10.3390/en1010003

[8] Y. Zhang, M. A. Dube, D. D. Mclean and M. Kates, "Biodiesel Production from Waste Cooking Oil: 1. Process Design and Technological Assessment," Bioresource Technology, Vol. 89, No. 1, 2003, pp. 1-16. doi:10.1016/S0960-8524(03)00040-3

[9] P. D. Patil, S. Deng, I. Rhodes and P. Lammers, "Conversion of Waste Cooking Oil to Biodiesel Using Ferric Sulfate and Supercritical Methanol Processes," Fuel , Vol. 89, No. 2, 2010, pp. 360-364. doi:10.1016/j.fuel.2009.05.024

[10] Y. Shimada, Y. Watanabe, A. Sugihara and Y. Tominaga, "Enzymatic Alcoholysis for Biodiesel Fuel Production and Application of the Reaction to Oil Processing," Journal of Molecular Catalysis B: Enzymatic, Vol. 17, No. 3-5, 2002, pp. 133-142. doi:10.1016/S1381-1177(02)00020-6

[11] F. R. Ma and M. A. Hanna, "Biodiesel Production: A Review," Bioresource Technology, Vol. 70, No. 1, 1999, pp. 1-15. doi:10.1016/S0960-8524(99)00025-5

[12] P. R. Muniyappa, S. C. Brammer and H. Noureddini, "Improved Conversion of Plant Oils and Animal Fats into Biodiesel and Co-Product," Bioresource Technology, Vol. 56, No. 1, 1996, pp. 19-24. doi:10.1016/0960-8524(95)00178-6

[13] M. P. Dorado, E. Ballesteros, F. J. Lopez and M. Mittelbach, "Optimization of Alkali-Catalyzed Transesterification of Brassica Carinate Oil for Biodiesel Production," Energy Fuels, Vol. 18, No.1, 2004, pp. 77-83. doi:10.1021/ef0340110

[14] G. Antolin, F. V. Tinaut, Y. Briceno, V. Castano, C. Perez and A. I. Ramirez, "Optimization of Biodiesel Production by Sunflower Oil Transesterification," Bioresource Technology, Vol. 83, No. 2, 2002, pp. 111-114. doi:10.1016/S0960-8524(01)00200-0

[15] N. E. Leadbeater and L. M. Stencel, "Fast, Easy Preparation of Biodiesel Using Microwave Heating," Energy Fuels, Vol. 20, No. 5, 2006, pp. 2281-2283. doi:10.1021/ef060163u

[16] A. A. Refaat, S. T. Sheltawy and K. U. Sadek, "Optimum Reaction Time, Performance and Exhaust Emissions of Biodiesel Produced by Microwave Irradiation," International Journal of Environmental Science and Technology, Vol. 5, No. 3, 2008, pp. 315-322. 
[17] S. Deng and Y. S. Lin, "Microwave Heating Synthesis of Supported Sorbents," Chemical Engineering Science, Vol. 52, No. 10, 1997, pp. 1563-1575. doi:10.1016/S0009-2509(97)00495-8

[18] P. Patil, G. Veera, A. Mannarswamy, S. Deng, P.Cooke, S. Munson-McGee, P. Lammers and N. Khandan, "Optimization of Microwave-Assisted Transesterification of Dry Algal Biomass Using Response Surface Methodology," Bioresource Technology, Vol. 102, No. 2, 2011, pp. 1399-1405. doi:10.1016/j.biortech.2010.09.046

[19] N. Azcan and A. Danisman, "Alkali Catalyzed Transesterification of Cottonseed Oil by Microwave Irradiation," Fuel, Vol. 86, No. 17-18, 2007, pp. 2639-2644. doi:10.1016/j.fuel.2007.05.021

[20] I. Roy and M. N. Gupta, "Applications of Microwaves in Biological Sciences," Current Science, Vol. 85, No. 12, 2003, pp. 1685-1693.

[21] M. Canakci and J. Van Gerpen, "Biodiesel Production from Oils and Fats with High Free Fatty Acids," American Society of Agricultural and Engineers, Vol. 44, No. 6, 2001, pp. 1429-1436.

[22] A. S. Ramadas, S. Jayraj and C. Muraleedharan, "Biodiesel Production from High FFA Ubber Seed Oil," Fuel, Vol. 84, No. 4, 2005, pp. 335-340. doi:10.1016/j.fuel.2004.09.016

[23] P. D. Patil, V. G. Gude, L. M. Camacho and S. Deng, "Microwave-Assisted Catalytic Transesterification of Camelina Sativa Oil," Energy Fuels, Vol. 24, No. 2, 2010, pp. 1298-1304. doi:10.1021/ef9010065

[24] F. Ma, L. D. Clements and M. A. Hanna, "The Effects of Catalysts, Free Fatty Acids, and Water on Transesterification of Beef Tallow," Transactions of American Society of Agricultural and Engineers, Vol. 41, No. 5, 1998, pp. 1261-1264.

[25] M. Canakci and J. Van Gerpen, "Biodiesel Production via Acid Catalysis," Transactions of American Society of Agricultural and Engineers, Vol. 42, No. 5, 1999, pp. 12031210.

[26] S. Zhang, Y. G. Zu, Y. J. Fu, M. Luo, D. Y. Zhang and T. Efferth, "Rapid Microwave-Assisted Transesterification of Yellow Horn Oil to Biodiesel Using a Heteropolyacid Solid Catalyst," Bioresource Technology, Vol. 101, No. 3, 2010, pp. 931-936. doi:10.1016/j.biortech.2009.08.069

[27] J. H. Kim, B. S. Kang, M. J. Kim, Y. M. Park, D. K. Kim, J. S. Lee and K. Y. Lee, "Transesterification of Vegetable Oil to Biodiesel Using Heterogeneous Base Catalyst," Catalysis Today, Vol. 93-95, 2004, pp. 315-320. doi:10.1016/j.cattod.2004.06.007

[28] A. J. Gotch, A. J. Reeder and A. J. McCormick, "Study of Heterogeneous Base Catalysts for Biodiesel Production," Journal of Undergraduate Chemistry Research, Vol. 4, 2008, pp. 58-62.

[29] A. W. Coats and J. P. Redfern, "Thermogravimetyric Analysis: A Review,” Analyst, Vol. 88, No. 1053, 1963, pp. 906-924. doi:10.1039/an9638800906 